\title{
MICROBIAL QUALITY OF IMPORTED FROZEN Sardinella species AND Micromesistius poutassou OFFERED FOR SALE IN OYO STATE, NIGERIA.
}

\author{
Olaolu O. Fawole and Olusegun A. Oyelese \\ Department of Aquaculture and Fisheries Management, University of Ibadan, Ibadan, Nigeria.
}

\begin{abstract}
Microbial quality of frozen fish offered for sale in Oyo state markets was investigated. The four Agricultural Development Programme (ADP) zones of the state were used for the study. Sardinella species and Micromesistius poutassou were selected among the commercially important imported frozen fish species in the state based on their availability in all zones. Bacterial and Fungal counts were determined using standard procedures. Data were analysed using descriptive statistics, percentages and t-test. Ten bacteria and three fungi and three yeast species were isolated from the fishes evaluated. Predominant bacteria isolates were Shewanella putrefaciens and Streptococcus faecium, fungi included Penicillium notatum and Aspergillus niger while yeast were Cryptococccus laurentii and Torulaspora debrueckii. Total viable counts for bacterial and fungal counts were $3.1 \times 10^{5} \mathrm{cfu} / \mathrm{g}$ and $1.8 \times 10^{5} \mathrm{cfu} / \mathrm{g}$, respectively for Sardinella spp. and $3.2 \times 10^{5} \mathrm{cfu} / \mathrm{g}$ and $2.4 \times 10^{5} \mathrm{cfu} / \mathrm{g}$ for $M$. poutassou. Although all the fish samples were within acceptable limit, the number of bacteria isolated showed that the quality of frozen fish did not reach expected standard in Oyo state.
\end{abstract}

Keywords: Microbial quality; Frozen fish; Bacteria count; Fungi count, ADP zones

DOI: $10.7176 / \mathrm{FSQM} / 85-08$

Publication date:March $31^{\text {st }} 2019$

\section{Introduction}

One-fourth of the world's food supply and $30 \%$ of landed fish are lost through microbial activities alone (Huis in't Veld, 1996 and Amos, 2007). Freezing is a widely used and accepted technology for preserving fish and fish products in their natural states (Tolstorebrov et al., 2016). However, quality deterioration of stored fish is inevitable with length of storage period (Jeon et al., 2002). Frozen fish displays third order biotic activity. It belongs to the class of foods in which the respiration process is suspended, but in which biochemical, microbial and other decomposition processes which must be taken into account still proceed (Huss et al., 1992). Fish and bacteria exist in a state of equilibrium and it is only after death that bacteria can invade the tissue and spoil the fish (Clucas, 1990; Aberounmand, 2010). Bacteria according to Eyo (2001) secrete digestive juices and enzymes which breakdown the tissue and cause spoilage of fish. This results in loss of flavour and odour and is replaced by a sour and stale odour. Fish carry a flora of psychrotrophic bacteria, most of which survive freezing; and are ready to grow on thawing (Twiddy and Reilly, 1995). Fish may harbor a number of biohazards as well as chemical contaminations such as biogenic amines, biotoxins, pathogenic bacteria and viruses if not properly handled (Ashie et al., 1996 and Gram et al., 2000).

Contamination concern has been on high loads of unsuspected spoilage microorganisms like Salmonella spp., Staphylococcus aureus, Pseudomonas aeruginosa and Escherichia coli (Bramsnacs, 1999). During spoilage, microbes mainly bacteria spoil the fish to such an extent that it cannot be edible (Abbas et al., 2009). Consumers are however becoming more aware of possible hazards, malpractices and mistakes arising from the food they consume and are individually and collectively becoming more demanding in respect of freshness, naturalness, microbial safety, freedom from pollutants, protection from damage and convenience. There is a need for determination of spoilage parameters to minimize losses, thereby increasing the quality of fish available for human consumption in many of the developing countries.

The objective of this study therefore is to evaluate the microbial load of frozen fish offered for sale in Oyo state markets and its effects on wholesomeness and safety of the product.

\section{Materials and Methods}

2.1 Microbiological Analysis

2.2 Sample collection

Frozen samples of Sardinella species (sardine) and Micromesistius poutasssou (blue whiting) were collected from the retail depots at different zones on bi-monthly basis for a period of twelve months between January and 
December. The two different samples were wrapped with aluminum foil and placed in sterile plastic containers with ice and conveyed to the laboratory for microbiological analysis.

\subsection{Sample Preparation}

The samples of Sardinella species and Micromesistius poutasssou were aseptically removed from the plastic container and were placed on a sterile tray and with the aid of a sterile knife; cuts were made from the edible parts of the samples. $90 \mathrm{ml}$ peptone water was added to $10 \mathrm{~g}$ of fish flesh and homogenized in a blender for a minute at high speed. $10 \mathrm{ml}$ of the original homogenate fluid was then taken for microbiological analysis.

\subsection{Culture Media}

Plate Count Agar (PCA), Mac Conkey Agar (MCA), Mannitol Salt Agar (MSA), Salmonella Shigella Agar (SSA), Potato Dextrose Agar (PDA), Blood Agar (BA) De Man, Rogosa Sharpe (MRS) Agar and Yeast Extract Agar (YEA) were weighed and distilled water was added according to Manufacturer's instruction. The solution was homogenised in a water bath for 10 minutes. The medium was then sterilized in an autoclave at $121^{\circ} \mathrm{C}$ for 15 minutes and allowed to cool to $45^{\circ} \mathrm{C}$ before use.

\subsection{Enumeration and Isolation of Microorganisms}

Serial dilutions were made from the samples using sterile pipette. This was done by mixing $1 \mathrm{~g}$ of the sample thoroughly with $9 \mathrm{ml}$ of sterile distilled water to give $1: 10$ dilution. The dilution was made up to $10^{-6}$. Using sterile pipette of $1 \mathrm{ml}$, appropriate dilutions were plated out using different culture media (Harrigan and McCance, 1976). The plates were inoculated in duplicates and allowed to set. After solidifying, MRS plates were incubated in a carbon-dioxide enriched jar at $37^{\circ} \mathrm{C}$ for 48 hours. Other bacterial plates were incubated aerobically at $30^{\circ} \mathrm{C}$ for 24 hours, while Potato Dextrose Agar plates were incubated for 3-5 days. At the end of incubation, representative colonies were selected at random and sub- cultured repeatedly to obtain pure cultures.

The culture media were used in the isolation and enumeration of the microbial loads of the fish samples. PCA for Total Viable Count, MCA was used for Enterobacteriaceae count, SSA for Salmonella and Shigella count, MSA for Staphylococcus count, MRS for Lactic acid bacteria, BA for haemolytic Streptococci count, PDA for fungi load and YEA for Yeast count using the pour plate technique. All isolated colonies were counted and expressed as colony forming units (CFU/g) per gram of fish.

\subsection{Characterization of the Isolates}

Characterization of the isolates was carried out by employing macroscopic, microscopic, biochemical and physiological tests such as Gram's staining, catalase test, use of API 20E and API 50 CH strips and medium for Enterobacteriaceae and lactic acid bacteria respectively (Willey et al., 2008; Zwadyw et al., 1977).

\subsection{Characterization of Staphylococcus isolates}

The tests employed in characterizing the isolates included Gram reaction, motility test, production of catalase, coagulase, starch hydrolysis, utilization of glucose, sucrose, lactose, mannitol, maltose, xylose, fructose and galactose. Identification to the generic level was done using Bergey's manual of determinative bacteriology (Holt et al., 2000) as a reference of identification based on the result of the various biochemical tests obtained.

\subsection{Cultural and Morphological Characterization of Fungal isolates}

The isolates were characterized based on the pigmentation of the spores, nature of the mycelia and spores formed. Microscopic details were studied by performing a wet mount using lactophenol cotton blue mounting fluid. The preparation was examined under objective lens. The fungi were identified as detailed by Barnet and Hunter (1972), Rhode and Hartmann (1980), Kulwant et al. (1991) and Larone (2002).

\subsection{Characterization and Identification of Yeast isolates}

This was carried out employing standard morphological, physiological and sugar fermentation pattern tests. Idenitification was done using identification keys described by Barnett et al. (2000). Yeast isolates were further characterized by the conventional methods as described by Kreger Van Rij (1984).

\subsection{Statistical Analysis}

The statistical programme, (SPSS, 2003) VERSION 16.0 was used to analyze the result of the treatments. Descriptive statistics and percentages were used for the data collected while T-test was used to determine whether there was a difference in microbial load of the two frozen fish species examined. 


\section{Results}

3.1 Microbiological Evaluation of Samples

The Total Bacteria Count of imported frozen fish across the four zones of the study area as shown in Table 1 indicates that the highest Total Viable Count $\left(3.1 \times 10^{5} \mathrm{cfu} / \mathrm{g}\right)$ was from Ogbomoso zone in Sardinella spp. fish samples, while the lowest was from Oyo zone $\left(1.2 \times 10^{5} \mathrm{cfu} / \mathrm{g}\right)$. In $M$. poutasssou, the highest TVC was also in Ogbomoso zone $\left(3.2 \times 10^{5} \mathrm{cfu} / \mathrm{g}\right)$ and the lowest in Oyo zone $\left(1.5 \times 10^{5} \mathrm{cfu} / \mathrm{g}\right)$. The highest Total SalmonellaShigella Count (TSSC) in Sardinella spp. samples was recorded in Ogbomoso zone $\left(6.9 \mathrm{x} 10^{3} \mathrm{cfu} / \mathrm{g}\right)$ and the least was from Oyo zone $\left(4.1 \times 10^{3} \mathrm{cfu} / \mathrm{g}\right)$. The highest TSSC in M. poutasssou was recorded in fish samples collected in Saki zone $\left(1.0 \times 10^{4} \mathrm{cfu} / \mathrm{g}\right)$ and the least $\left(4.9 \times 10^{3} \mathrm{cfu} / \mathrm{g}\right)$ was from Oyo zone. Total Haemolytic Streptococci Count (THSC) in Sardinella species was highest in Oyo zone $\left(3.5 \times 10^{4} \mathrm{cfu} / \mathrm{g}\right)$ and the least was in Saki zone (2.8 $\left.\mathrm{x} 10^{4} \mathrm{cfu} / \mathrm{g}\right)$. Ogbomoso zone $\left(3.5 \times 10^{4} \mathrm{cfu} / \mathrm{g}\right)$ recorded the highest THSC in M. poutasssou, while Ibadan/Ibarapa recorded the least value of $3.1 \times 10^{4} \mathrm{cfu} / \mathrm{g}$. Total Lactic Acid Bacteria Count (TLAB) in Sardinella species was lower in Ibadan/Ibarapa, Ogbomoso and Saki zones than in M. poutasssou. Oyo zone was the only zone that recorded a higher TLAB count of $6.8 \times 10^{3} \mathrm{cfu} / \mathrm{g}$ in Sardinella spp. than M. poutasssou $\left(3.1 \times 10^{3} \mathrm{cfu} / \mathrm{g}\right)$.

Frozen samples collected from M. poutasssou had higher total Enterobacteriaceae Count (TEBC) in all zones compared to Sardinella species. The highest TEBC was recorded in Ogbomoso zone for both M. poutasssou (4.1 $\left.\times 10^{4} \mathrm{cfu} / \mathrm{g}\right)$ and Sardinella species $\left(3.1 \times 10^{4} \mathrm{cfu} / \mathrm{g}\right)$ while the least was $2.3 \times 10^{4} \mathrm{cfu} / \mathrm{g}$ in Ibadan/Ibarapa zone and $1.2 \times \times 10^{4} \mathrm{cfu} / \mathrm{g}$ in Oyo zone respectively. Highest Total Staphylococcus Count (TSC) for Sardinella spp. samples was recorded in Oyo zone $\left(3.0 \times 10^{3} \mathrm{cfu} / \mathrm{g}\right)$, while the least was in Saki zone $\left(1.0 \mathrm{x} \times 10^{4} \mathrm{cfu} / \mathrm{g}\right)$. In M. poutasssou samples, highest TSC $\left(6.6 \times 10^{3} \mathrm{cfu} / \mathrm{g}\right)$ was recorded in Ibadan/Ibarapa zone and the least $\left(1.0 \times 10^{3} \mathrm{cfu} / \mathrm{g}\right)$ in Oyo zone. However, M. poutasssou samples had higher Staphylococcus count than Sardinella species in Ibadan/Ibarapa, Ogbomoso and Saki zones, while the case was different in Oyo zone where Sardinella species had higher counts than M. poutasssou.

The frequency of occurrence of bacteria isolated in Sardinella species showed that Streptococcus faecium was highest with $16.8 \%$ followed by Shewanella putrefaciens $16.1 \%$ and Salmonella typhi $(14.8 \%)$, while the least bacteria count of $1.9 \%$ was recorded in Leuconostoc mesenteroides. In M. poutasssou samples, Shewanella putrefaciens also recorded the highest value of $16.5 \%$ followed by Salmonella typhi, 15.9\% and Streptococcus faecium $14.1 \%$ while the least value of $2.9 \%$ was recorded in Pediococcus damnosus. All the 10 bacteria species recorded in this study showed their occurrences in both Sardinella spp. and M. poutasssou fish samples with Shewanella putrefaciens, Streptococcus faecium and Salmonella typhi showing higher frequencies of occurrence in both fish species. In Table 2, the result of the t-test conducted on the mean values of the TVC of the two fish species across zones showed significant difference $(\mathrm{p}<0.05)$ in the two fish species.

Colonially, the size of the test isolates ranged from small to medium and their forms ranged from circular to irregular shapes. They had creamy, brownish to pinkish colouration with entire edges. Opacity ranged from translucent to opaque. They had raised elevation and consistency varied from friable, butryous to viscoid. The bacterial population of the frozen fish samples consisted of both Gram negative and Gram positive rods and cocci. The Gram negative bacterial isolates were catalase and oxidase negative, rod shaped, producing acid aerobically and anaerobically form glucose in Hugh-Leifson's medium and they were members of the family Enterobacteriaceae. The representative organisms identified were Salmonella typhi, Shewanella putrefaciens, Enterobacter asburiae, Pseudomonas aeruginosa and Proteus vulgaris. Gram positive isolates were catalase and oxidase negative, non-endospore forming fermentative organisms recognized as members of the lactic acid bacteria group. They included Lactobacillus acidophilus, Leuconostoc mesenteroides, Pediococcus damnosus and Streptococcus faecium (Table 3). The Staphylococcus aureus, also isolated from the samples was found to be coagulase and catalase positive and did not ferment lactose, glucose and fructose, but were found to ferment only sucrose. The strains were also mannitol-positive, but found to be indole and motility negative and grampositive cocci bacteria.

Table 1: Total Bacteria Count of imported frozen fish across the ADP zones

\begin{tabular}{|l|l|l|l|l|l|l|l|}
\hline Fish sample & Zones & $\begin{array}{l}\text { TVC } \\
(\mathrm{cfu} / \mathrm{g})\end{array}$ & $\begin{array}{l}\text { TSSC } \\
(\mathrm{cfu} / \mathrm{g})\end{array}$ & $\begin{array}{l}\text { THSC } \\
(\mathrm{cfu} / \mathrm{g})\end{array}$ & $\begin{array}{l}\text { TLAB } \\
(\mathrm{cfu} / \mathrm{g})\end{array}$ & $\begin{array}{l}\text { TEBC } \\
(\mathrm{cfu} / \mathrm{g})\end{array}$ & $\begin{array}{l}\text { TSC } \\
(\mathrm{cfu} / \mathrm{g})\end{array}$ \\
\hline Sardinella & Ibadan/Ibarapa & $1.7 \times 10^{5}$ & $5.5 \times 10^{3}$ & $3.0 \times 10^{4}$ & $4.8 \times 10^{3}$ & $1.4 \times 10^{4}$ & $2.9 \times 10^{2}$ \\
\hline Species & Ogbomoso & $3.1 \times 10^{5}$ & $6.9 \times 10^{3}$ & $3.1 \times 10^{4}$ & $3.7 \times 10^{3}$ & $3.1 \times 10^{4}$ & $1.0 \times 10^{3}$ \\
\hline & Oyo & $1.2 \times 10^{5}$ & $4.1 \times 10^{3}$ & $3.5 \times 10^{4}$ & $6.8 \times 10^{3}$ & $1.2 \times 10^{4}$ & $3.0 \times 10^{3}$ \\
\hline & Saki & $1.4 \times 10^{5}$ & $5.9 \times 10^{3}$ & $2.8 \times 10^{4}$ & $3.8 \times 10^{3}$ & $2.2 \times 10^{4}$ & $1.7 \times 10^{3}$ \\
\hline Micromesistius & Ibadan/Ibarapa & $2.6 \times 10^{5}$ & $7.5 \times 10^{3}$ & $3.1 \times 10^{4}$ & $8.6 \times 10^{3}$ & $2.3 \times 10^{4}$ & $6.6 \times 10^{3}$ \\
\hline Poutassou & Ogbomoso & $3.2 \times 10^{5}$ & $9.5 \times 10^{3}$ & $3.5 \times 10^{4}$ & $9.5 \times 10^{3}$ & $4.1 \times 10^{4}$ & $1.5 \times 10^{3}$ \\
\hline & Oyo & $1.5 \times 10^{5}$ & $4.9 \times 10^{3}$ & $3.5 \times 10^{4}$ & $3.1 \times 10^{3}$ & $2.6 \times 10^{4}$ & $1.0 \times 10^{3}$ \\
\hline & Saki & $2.2 \times 10^{5}$ & $1.0 \times 10^{4}$ & $3.2 \times 10^{4}$ & $6.7 \times 10^{3}$ & $3.4 \times 10^{4}$ & $1.1 \times 10^{3}$ \\
\hline
\end{tabular}


Table 2: T- Test for Mean values of Quality indices in Sardinella species and Micromesistus poutassou across the ADP zones

\begin{tabular}{|l|l|l|l|l|l|l|l|}
\hline Parameter & Sample & N & $\overline{\boldsymbol{x}}+\boldsymbol{S E M}$ & Df & t-value & P Level & $(<\mathbf{0 . 0 5})$ \\
\hline $\begin{array}{l}\text { Log Total viable } \\
\text { count }\end{array}$ & $\begin{array}{l}\text { Sardinella } \text { spp. } \\
\text { M. poutasssou }\end{array}$ & 30 & $\begin{array}{l}0.2 \pm 0.10 \\
0.29 \pm 0.06\end{array}$ & 58 & -2.32 & 0.024 & $(<0.05)$ \\
\hline
\end{tabular}

Table 3: Frequency of occurrence of bacteria isolates in the fish samples across the ADP zones

\begin{tabular}{|l|l|l|}
\hline \multirow{2}{*}{ Bacteria Species } & \multicolumn{2}{|c|}{ Fish sample } \\
\cline { 2 - 3 } & Sardinella species (\%) & Micromesistius poutassou (\%) \\
\hline Salmonella typhi & 14.8 & 15.9 \\
\hline Streptococcus faecium & 16.8 & 14.1 \\
\hline Shewanella putrefaciens & 16.1 & 16.5 \\
\hline Enterobacter asburiae & 10.3 & 8.2 \\
\hline Pseudomonas aeruginosa & 9.0 & 12.4 \\
\hline Proteus vulgaris & 12.9 & 13.5 \\
\hline Lactobacillus acidophilus & 9.0 & 6.5 \\
\hline Leuconostoc mesenteroides & 1.9 & 4.1 \\
\hline Pediococcus damnosus & 3.2 & 2.9 \\
\hline Staphylococcus aureus & 5.8 & 5.9 \\
\hline Total & 100.0 & 100.0 \\
\hline
\end{tabular}

3.2 Mould and Yeast Isolates in the Imported Frozen Fish Samples.

Based on the pigmentation of the spores, nature of the mycelia and spore formation, Aspergillus niger, Penicillium notatum and Geotrichum species were isolated from the two frozen fish samples. As shown in Table 4, Oyo zone has the lowest fungal count in both Sardinella spp. $\left(7.9 \times 10^{4}\right)$ and M. poutassou $\left(1.4 \times 10^{5}\right)$ samples respectively. In Sardinella spp. samples, the highest fungal load was in Ogbomoso zone $\left(1.8 \times 10^{5}\right)$ while $M$. poutassou samples recorded $2.4 \times 10^{5}$ in both Ibadan/Ibarapa and Saki respectively. In Table 5, frequency of occurrence of fungal isolates for Sardinella spp. showed that Penicillium notatum with the highest occurrence of 63.9\%, Aspergillus niger (25\%) and Geotrichum species with the least (11.1\%). In M. poutasssou, Aspergillus niger had the highest occurrence (39.1\%), while both Penicillium notatum and Geotrichum species were $30.4 \%$ each respectively.

The yeast isolates were identified as Pichia farinose, Cryptococcus laurentii and Torulaspora delbrueckii. All yeast isolates fermented glucose, none was able to ferment xylose, arabinose and methanol while none utilize nitrate. In Table 6, yeast occurrence in Sardinella spp. samples shows Pichia farinose with highest (38.6\%), while Torulaspora delbrueckii and Cryptococcus laurentii had 31.8\% and 29.6\% respectively. In M. poutassou samples, Cryptococcus laurentii has the highest (42.9\%), Torulaspora delbrueckii $(32.6 \%)$ and Pichia farinose $(24.5 \%)$.

Table 4: Total Fungal count of imported Frozen Fish across the ADP zones

\begin{tabular}{|l|l|l|l|}
\hline Fish sample & ADP zones & Yeast count $(\mathrm{cfu} / \mathrm{g})$ & Fungal count $(\mathrm{cfu} / \mathrm{g})$ \\
\hline Sardinella species & Ibadan/Ibarapa & $1.7 \times 10^{5}$ & $1.6 \times 10^{5}$ \\
\hline & Ogbomoso & $1.8 \times 10^{5}$ & $1.8 \times 10^{5}$ \\
\hline & Oyo & $2.2 \times 10^{5}$ & $7.9 \times 10^{4}$ \\
\hline & Saki & $2.4 \times 10^{5}$ & $1.3 \times 10^{5}$ \\
\hline Micromesistius & Ibadan/Ibarapa & $2.1 \times 10^{5}$ & $2.4 \times 10^{5}$ \\
\hline Poutassou & Ogbomoso & $3.1 \times 10^{5}$ & $2.3 \times 10^{5}$ \\
\hline & Oyo & $2.6 \times 10^{5}$ & $1.4 \times 10^{5}$ \\
\hline & Saki & $2.8 \times 10^{5}$ & $2.4 \times 10^{5}$ \\
\hline
\end{tabular}


Table 5: Frequency of occurrence of Fungi isolates in Frozen fish sample across the ADP zones

\begin{tabular}{|l|l|l|}
\hline \multirow{2}{*}{ Fungi species } & \multicolumn{2}{|c|}{ Fish sample } \\
\cline { 2 - 3 } & Sardinella species (\%) & Micromesistius poutassou (\%) \\
\hline Penicillium notatum & 63.9 & 30.4 \\
\hline Aspergillus niger & 25.0 & 39.2 \\
\hline Geotrichum species & 11.1 & 30.4 \\
\hline
\end{tabular}

Table 6: Frequency of occurrence of Yeast isolates in Frozen fish sample across the ADP zones

\begin{tabular}{|l|l|l|}
\hline \multirow{2}{*}{ Yeast species } & \multicolumn{2}{|c|}{ Fish sample } \\
\cline { 2 - 3 } & Sardinella species (\%) & Micromesistus poutassou (\%) \\
\hline Pichia farinose & 38.6 & 24.5 \\
\hline Cryptococcus Laurentii & 29.6 & 42.9 \\
\hline Torulaspora Debrueckii & 31.8 & 32.6 \\
\hline
\end{tabular}

\section{Discussion}

The presence of contaminating bacteria in seafoods could be attributed to cross-contamination from the environment, source, and handling along the distribution chain (Bryant et al., 1988). The mean viable count of the organisms from the study was found to be within local and international standards (SON, 2004 and ICMSF, 2005) for frozen fish products which are between $5.0 \times 10^{5}$ and $1.0 \times 10^{6} \mathrm{CFU} \mathrm{g}^{-1}$.

In this study, Pseudomonas species was isolated from the fish samples collected from the four zones. The isolation of Pseudomonas spp. from experimental samples is important because Pseudomonas is a potential pathogen and spoilage agent (Koutsoumanis and Nychas, 2000; Jeyasekaran et al., 2006 and Yaqoub, 2009). Pseudomonas can survive freezing temperature and will resume growth when thawed (Frazier and Westhoff, 1988). This also corroborated Adebayo-Tayo et al. (2012), who isolated Pseudomonas spp. from frozen mackerel. Pseudomonas spp. also predominates in Oreochromis niloticus stored in ice (Farag, 2012).

Shewanella putrefaciens isolated from the fish samples is also a well-defined spoilage bacteria. It utilizes TMAO as the terminal electron acceptor in an anaerobic respiration resulting in off-odours and off- flavours due to formation of TMA (Dalgaard, 1995). Jorgensen (1988) and Jorgensen et al. (1989) also isolated S. putrefaciens in packed fish products and were observed to be capable of producing TMA and is indeed specific spoilage organism. S. putrefaciens and Pseudomonas were identified as specific spoilage organism of different types of fresh chilled fish when stored aerobically (Gram et al., 1990). Pseudomonas spp. appeared responsible for sweet, fruity spoilage odours while $S$. putrefaciens was responsible for the $\mathrm{H}_{2} \mathrm{~S}$ production (Olafsdottir et al., 2006). Lactic acid bacteria (LAB) were also isolated from the fish samples. As observed by Schroder et al. (1980), LAB occurs naturally in fish and they are easily outgrown by the Gram-negative bacteria during iced, aerobic storage. This could have accounted for why there were more Enterobacteriaceae isolates in the fish samples examined.

Staphylococcus aureus encountered in this study is in agreement with previous study by Eze et al. (2011) who isolated S. aureus in frozen mackerel. According to Adams and Moss (2000), Staphylococcus aureus is not a part of the normal flora of fish and fish products and the enumeration of $S$. aureus in food products is employed generally as a sanitation index. Staphylococcus aureus as an indicator of contamination of processed foods could come from the skin, mouth or nose of handlers (Clucas and Ward, 1996 and Acco et al., 2003). Staphylococcus aureus causes many outbreaks of food poisoning resulting from hand contact (Bryant et al., 1988). Streptococcus faecium was also isolated from the fish samples in agreement with FAO (1994) which observed that the organism is relatively resistant to freezing, which makes it potentially useful as an indicator organism for evaluating plant hygiene during processing of frozen food. However, many foods including fish products contain these organisms as normal part of their flora and they are also able to establish themselves and persist in a food processing plant.

The presence of other indicator organisms like Enterobacter and Salmonella was also reported by Okonko et al. (2008) who isolated Enterobacter aerogenes and Salmonella sp. in frozen seafood. Salmonella is normally not present on fish, but fish products may become contaminated during processing, storage, distribution or preparation for consumption (Huss et al., 1987, Panisello et al., 2000). The heat resistance of Salmonella is however very low, they are killed by pasteurization temperature and time (Bikek, 2001). The significance of the $\mathrm{t}$ - test on the mean values of the TVC between the two fish species implied that there was marked difference in the mean microbial load contents of both Sardinella species and Micromesistius poutassou. The presence of fungal isolates in the fish samples is in agreement with previous findings by Wogu and Maduakor (2011), who reported the presence of similar fungal species in fresh fish samples. Three fungi and three yeast species were isolated in each of the two frozen fish samples. This was fewer compared to bacteria isolates which were ten. 
This corroborated earlier submission by Clucas (1990) that where water is abundant, bacteria grow much more rapidly and moulds are only of secondary importance and yeast are not important as far as sea foods are concerned but moulds, due to their ability to grow where water is limited, could be a problem on smoked or dried fish.

\section{Conclusion}

Total viable count (TVC), Total Staphylococcus Count (TSC), Total Haemolytic Streptococcus Count (THSC), Total Lactic Acid Bacteria count (TLAB) and Total Enterobacteriaceae Count (TEBC) were all within the Standard Microbiological Limit of $5.0 \times 10^{5}$ and $1.0 \times 10^{6} \mathrm{CFU} \mathrm{\textrm {g } ^ { - 1 }}$ across zones except for Total Salmonella Shigella count (TSSC) which was higher than the acceptable limit. However, for all the quality indices evaluated across zones, Micromesistius poutassou had higher values than Sardinella species, which implied that $M$. poutasssou had higher pathogenic and spoilage potential than Sardinella spp. in the study area. Oyo zone had the highest quality of frozen fish, while Ogbomoso zone had the least quality amongst the four ADP zones of the state.

Although all the fish samples were within acceptable limit for consumption and their threshold values in terms of microbial load were not exceeded, the number of bacteria isolated showed that the quality of frozen fish did not reach expected standard in Oyo state. However, these products did not constitute any health risk or hazard since they would still be properly cooked before consumption.

\section{Acknowledgements}

Our express gratitude to Dr. S. T. Ogunbanwo, Prof. B. O. Omitoyin, Prof. E. K. Ajani and Dr. (Mrs.) O.O. Olusola, University of Ibadan. Also, we thank Prof. (Mrs.) F.O.A. George, Federal University of Agriculture, Abeokuta and Mr. Gbenro Adeyemo, Department of Microbiology, University Teaching Hospital (UCH), Ibadan for their technical assistance at making this research a success.

\section{References}

Abbas, K.A., Saleh, A.M., Mohammed, A and Lasekan, O. (2009). The relationship between activity and fish spoilage during cold storage: A review. J. Food, Agric. Environ.,

water with spoilage of cod fish. World Journal of fish and Marine Sciences 2 (30): 200- 203

Acco, M., Ferreira, F.S., Henriques, J.A.P. and Tondo, E.C. (2003). Identification of multiple strains of Staphylococcus aureus colonizing nasal mucosa of food handlers. Food Microbiology 20: 489-493.

Adams, M.R. and Moss, M.O. (2000). Food Microbiology. The Royal Society of Chemistry Science Park, Cambridge. $447 \mathrm{pp}$.

Adebayo-Tayo, B.C., Odu, N.N., Anyamele, L.M., Igwiloh N.J.P.N and Okonko, I.O. (2012). Microbial Quality of Frozen Fish Sold in Uyo Metropolis. Nature and Science 10 (3): 71-77.

Amos, B. (2007). Analysis of quality deterioration at critical steps/points In: Fish handling in Uganda and Iceland and suggestion for improvement. United Nations University, Uganda.

Ashie, I.N.A., Smith, J.P., Simpson, B.K. and Haard, N. F. (1996). Spoilage and shelf life extension of fresh fish and shell fish. Critical Reviews in food Science and Nutrition 36: 87- 121. https://doi.org/10.1080/10408399609527720

Barnett, H.L. and Hunter, B.B. (1972). Illustrated Genera of Imperfect Fungi. 3rd edition. Burgess publishing company, Washington D.C.

Barnett, I. A, Payee, P.W and Yarrow D. (2000). Yeasts: Characterization and Identification. 3rd edition. Cambridge University Press, Cambridge.

Bramsnacs, F. (1999). Handling of fresh fish. G. Borgstrom Ed. Fish as food. Arnord Publishers, London.

Bibek, R. (2001). Fundamental Food Microbiology. 2nd edition. London: CRC Press LLC.

Bryant, R.G., Jarvis, J. and Guilbert, G. (1988). Selective enterotoxin production by a Staphylococcus aureus strain implicated in a food borne outbreak. J. Food production. 51: 130-131. https://doi.org/10.4315/0362-028x-51.2.130

Clucas, I.J. and Ward, A.R. (1996). Post harvest fisheries development: A Guide to Handling, Preservation, Processing and Quality. Charthan Maritime, Kent M44TB, United Kingdom.

Clucas, I.J. Ed. (1990). Fish Handling, Preservation and Processing in the Tropics. Tropical and Research Institute, London. 141pp.

Dalgaard, P. (1995). Modeling of microbial activity and prediction of shelflife for packed fresh fish. Int. J. Food Microbiol. 26: 305-317. https://doi.org/10.1016/0168-1605(94)00136-t

Eyo, A.A. (2001). Fish Processing Technology in the Tropics. University of Ilorin press, Nigeria. 403pp.

Eze, E.I., Echezona, B.C and Uzodinma, E.C. (2011). Isolation and identification of pathogenic bacteria associated with frozen mackerel fish (Scomber scrombrus) in a humid tropical environment. African 
Journal of Agricultural Research. 6(8): 1947-1951.

Farag, H.E.M. (2012). Sensory and chemical changes associated with microbial flora of Oreochromis niloticus stored in ice. International Food Research Journal. 19(2):447-453.

Frazier, W.C. and Westhoff, D.C. (1988). Food Microbiology. 4th Edition. Mc Graw-Hill College. 539pp.

Food and Agriculture Organization (FAO). (1994). Assurance of Seafood Quality. Fisheries Technical Paper 344, 224pp.

Gram, L., Wedell-Neergaard, C. and Huss, H.H. (1990). The bacteriology of spoiling lake Victoria Nile Perch (Lates niloticus). Int. J. Food Microbiol., 10: 303-316.

Gram, L., Oundo, J.O. and Bon, J. (2000). Shelf life of fish depends on storage temperature and initial bacteria load. Tropical Science. 25: 28-30.

Harrigan, W.F. and McCance, M.E. (1976). Laboratory Methods in Food and Dairy Microbiology. Academy Press, London, UK. P452.

Holt, J.G., Krieg, N.R., Sneath, P.H.A., Staley, J.T. and Williams, S.T. (2000). Bergey's Manual of Determinative Bacteriology. 9th Edition. 787pp.

Huis in't Veld, J.H.J. (1996). Microbial and biochemical spoilage of foods: An overview. Int. J. Food Microbiol., 33: 1-18. https://doi.org/10.1016/0168-1605(96)01139-7

Huss, H.H., Jakobsen, M. and Liston, J. (1992). Quality assurance in the fish industry. Development in Food Science 30: 93-115. Elsevier Science Publishers B.V.

Huss, H.H., Trolle, G. and Gram, L. (1987). New rapid methods in microbiological evaluation of fish quality. In: Seafood Quality Determination. D.E. Kramer and J. Liston. Eds. Elsevier, Amsterdam. Pp299-308.

International Commission on Microbiological Specifications for Foods (ICMSF). (2005). Microorganisms in fish and fish products. Microbial Ecology of food commodities. Kluwer Academic/plenum Publishers. NewYork pp 172-249.

Jeon, Y.J., Kamil, J.Y. and Shahidi, F. (2002). Chitosan as an edible invisible film for quality preservation of Herring and Atlantic cod. J. Agric. Food Chem. 50(18): 5167-5178.

Jeyasekaran, G., Ganesan, P., Anandaraj, R.J. and Sukumar, D. (2006). Quantitative and Qualitative studies on the Bacteriological Quality of Indian white shrimp (Penaeus indicus) stored in dry ice. Food Microbiol. 23(6): 526-533. https://doi.org/10.1016/j.fm.2005.09.009

Jorgensen, B.R. (1988). Microbiology quality and shelflife prediction of chilled fish. Int. J. Food Microbiology. 6: 295-307. https://doi.org/10.1016/0168-1605(88)90023-2

Jorgensen, B.R. and Huss, H.H. (1989). Growth and activity of Shewanella putrefaciens isolated from spoiling fish. Int. J. Food Microbiol. 9: 51-62.

Koutsoumanis, K. and Nychas, G.J.E. (2000). Chemical and sensory changes associated with microbial flora of Meditteranean boque (Boops boops) aerobically stored at 0, 3, 7 and

100C. Journal of Applied and Environmental Microbiology. 65(2): 698-706.

Kreger-Van Rij, N.J.W. (1984). The Yeasts: A taxonomic study. Elsevier Science Publishers, $1984-$ Science. $1082 \mathrm{pp}$.

Kulwant, S., Frisvad, J. C., Thrane, U. and Martha, S.B. (1991). An illustrated Manual in Identification of Sea-borne Aspergillus, Fusaria, Penicillia and their Mycotoxins. 1st Edition. Danish institute of seed pathology, Copenhagen.

Larone, D.H. (2002). Medically Important Fungi: A Guide to Identification. 4th edition. ASM Press, Washington D. C. 409pp.

Okonko, I.O., Ogunjobi, A.A., Adejoye, O.D., Ogunnusi, T.A. and Olasogba, M.C. (2008). Comparative studies and Microbial risk assessment of different water samples used for processing frozen sea foods in Ijora Olopa, Lagos State, Nigeria. African Journal of Biotechnology (AJB) 7(16): 29022907.

Olafsdottir, G., Lauzon, H.L., Martinsdottir, E and Kristbergsson, K. (2006). Influence of storage temperature on microbial spoilage characteristics of haddock fillets (Melanogrammus aeglefinus) evaluated by multivariate quality prediction. Int. J. Food Microbiol., 111: 112- 125. https://doi.org/10.1016/j.ijfoodmicro.2006.04.045

Panisello, P.J., Rooney, R., Quantik, P.C and Stanwell-Smith, R. (2000). Application of food borne disease outbreak data in the development and maintenance of HACCP systems. International Journal of Food Microbiology. 59:221-234.

Rhode, B. and Hartmann, G. (1980). Introducing Mycology by Examples. Michalein Press, Toronto.138pp.

Ryser, E.T., Marth, E.H. and Taylor, S.L. (1984). Histamine production by psychrotrophic Pseudomonas isolated from tuna fish. J. food Protection 47: 378-380.

Schroder, K., Clausen, E., Sandberg, A.M. and Raa, J. (1980). Psychrotrophic Lactobacillus plantarum from fish and its ability to produce antibiotic substances. In: Advances in Fish Science and 
Technology. J.J. Connell. Ed. Pp.480-483. Fishing News Books.

SPSS. (2003). Statistical package for social science for Windows 16. SPSS Inc., Chicago, IL, and USA.

Standards Organization of Nigeria (SON). (2004). Code of practice for fish and fishery products. 120.30. 43pp.

Tolstorebrov, I., Eikevik, T.M and Bantle, M. (2016). Effect of low and ultra-low temperature during freezing and frozen storage on quality parameters for fish. International Refrigeration.63:37-47. https://doi.org/10.1016/j.ijrefrig.2015.11.003

Twiddy, D. and Reilly, P.J. (1995). Occurrence of Antibiotic Resistance human pathogens in integrated fish farms. Research contributions. Presented at the 9th session of the Indo- Pacific Fisheries Commission working party on fish technology and marketing. Cochin- India, 7-9 March. No 514. Supp: 23-37.

Willey, J. M., Sherwood, L.M. and Woolverton, C.J. (2008). Prescott, Harley and Klein's $\quad$ Microbiology. 7th Edition. McGraw-Hill, London. Pp113-118.

Wogu, M.D. and Maduakor, C.C. (2011). Evaluation of Microbial spoilage of some aquacultured fresh fish in Benin City, Nigeria. Ethiopian. J. of Envir.Stud.and Mgt. Vol.3. pp18-22. Yaqoub, S.O. (2009). Isolation of Enterobacteriaceae and Pseudomonas spp. From raw fish sold in fish market in Khartoun state. Journal of bacteriological Research 1 (7): 085-088.

Zwadyw, P. J.R., Tarlton, R.A. and Proctor, A. (1977). Evaluation of the API 20C for the identification of yeasts. America Journal of Clinical Pathology, 67: 269-271. 